\title{
Synthesis, Structural and Optical Characterization of Copper and Rare Earth doped CdS Nanoparticles
}

\author{
Sonika Khajuria, ${ }^{1}$ Sumit Sanotra, ${ }^{1}$ Heena Khajuria, ${ }^{1}$ Anuraag Singh ${ }^{2}$ \\ and Haq Nawaz Sheikh ${ }^{1, *}$ \\ ${ }^{1}$ Department of Chemistry, University of Jammu, Jammu Tawi, 180006 India \\ ${ }^{2}$ Electron Microscope Facility, Department of Anatomy, All India Institute of Medical Sciences (AIIMS), New Delhi-110029 \\ * Corresponding author: E-mail: hnsheikh@ rediffmail.com \\ Tel.: +91-191-2493124; Fax: +91-191-2431365
}

Received: 15-09-2015

\begin{abstract}
Cadmium sulphide $(\mathrm{CdS})$ nanoparticles doped with $\mathrm{Cu}^{2+}$ and co-doped with rare earth metallic ions $\left(\mathrm{Ln}^{3+}\right)$ have been synthesized by co-precipitation method. The synthesized nanoparticles were characterized by powder X-ray diffraction studies (PXRD), scanning electron microscopy (SEM), transmission electron microscopy (TEM), particle size by dynamic light scattering (DLS), UV-visible spectroscopy (UV), and photoluminescence (PL) studies. It is observed that CdS nanoparticles can be co-doped with copper and rare earth metallic ions without altering XRD pattern as indicated by X-ray diffraction results. SEM and TEM results show that synthesized particles have spherical aggregation. Absorption spectra of all the samples show strong blue shift from bulk CdS. Interesting luminescence pattern with enhanced intensity has been observed for co-doped CdS nanoparticles at room temperature.
\end{abstract}

Keywords: Nanoparticles; CdS nanoparticles; PXRD; absorption; photoluminescence.

\section{Introduction}

In the past few decades, synthesis of nanoscale materials in the field of nanotechnology has attracted attention to due to their unique physical and chemical properties. ${ }^{1-4}$ Generally their properties are highly dependent on the size and morphology. ${ }^{5,6}$ Much emphasis has been laid on the synthesis and characterization of semiconductor nanoparticles due to their significant quantum confinement effects. These effects result in significant variation in electrical and optical properties of nanoparticles. Doped nanosized semiconductors were studied due to their potential applications in optoelectronic nanodevices and functional materials. ${ }^{7-10}$ Doping of materials allows to noticeably modify the properties of materials. Because of their excellent luminescent properties, transition metal and rare earth ions doped semiconductor nanostructures have been the subject of numerous investigations. ${ }^{11-15}$ The doped nanostructures are known to have unusual physical and chemical properties in comparison with the corresponding bulk materials. ${ }^{16-18}$ Among chalcogenides, special photoelectrical and chemical properties of CdS (band gap $2.42 \mathrm{eV}$ at $300 \mathrm{~K}$ for bulk $\mathrm{CdS}$ and $3.25 \mathrm{eV}$ for nanosized $\mathrm{CdS}^{19}$ ) have generated much interest because of its relatively large nonlinear response,${ }^{20}$ photocatalytic activity $^{21}$ and luminescence. ${ }^{22}$ Both size and surface effects are important in nanosized materials. ${ }^{23}$ It is possible to design materials of required optical, electrical, magnetic, elastic and chemical properties by controlling both these effects. The nature of the dopant ion strongly influences the luminescent properties of doped nanoparticles as they play an important role in changing the electronic structure and transition probabilities of the host materials.

G. Giribabu and co-workers have reported the structural, optical and magnetic properties of cobalt and aluminium co-doped CdS nanoparticles synthesized by simple co-precipitation method. ${ }^{24}$ A. Sundaria et al. have synthesized star-shaped copper doped CdS nanoparticles and have studied the relation between shape and antibacterial properties of the nanoparticles. ${ }^{25}$ Xiaohui Wang et al. have reported the synthesis of lanthanide doped $\mathrm{CdS}$ and $\mathrm{ZnS}$ quantum dots in natural polysaccharide template and studied their optical properties. ${ }^{26} \mathrm{M}$. Thambidurai and co- 
workers have studied the structural, optical and electrical properties of cobalt doped CdS Quantum dots. They have carried a systematic study to understand the influence of co-doping on various properties of $\mathrm{CdS}$ nanoparticles. ${ }^{27}$ Magnetic and structural characterization of $\mathrm{Ni}$ and $\mathrm{Cu}$ codoped $\mathrm{CdS}$ nanoparticles has been carried out by $\mathrm{S}$. $\mathrm{Ku}-$ mar and co-workers. ${ }^{28} \mathrm{P}$. Yang et al. have reported a new class of luminescent materials by synthesizing $\mathrm{ZnS}$ nanocrystals co-activated by transition metals and rare earths. ${ }^{29}$ Generally, the properties of the dopant are mainly reflected in luminescence of rare-earth doped systems. Incompletely filled $4 \mathrm{f}^{\mathrm{n}}$ shells result in different electronic structure of rare-earth ions as compared to other elements. The $5 \mathrm{~s}^{2}$ and $5 \mathrm{p}^{6}$ electron orbitals shield the $4 \mathrm{f}^{\mathrm{n}}$ electrons. A sharp line emission is observed on exciting such doped materials due to intra $4 \mathrm{f}^{\mathrm{n}}$ shell transition of rare earth ion core which lies in a wide range covering UV, Vis and IR regions of the spectrum. ${ }^{30}$ There is little work done on luminescence studies related to semiconductor nanoparticles co-activated with two kinds of (transition and rare earth) metallic ions.

A number of techniques have been utilized to synthesize doped nanoparticles such as sol-gel, solid state reaction, co-precipitation etc. ${ }^{31,32}$ In the present work, doped CdS nanoparticles were synthesised by co-precipitation method as it is inexpensive and more yield producing method. Herein, we report the structural and optical characterization of $\mathrm{CdS}$ semiconductor nanoparticles co-doped with $\mathrm{Cu}^{2+}$ and rare earth ions $\left(\mathrm{Ln}^{3+}\right)$ synthesized by co-precipitation method.

\section{Experimental}

\section{1. Materials and Measurements}

All the reagents were of analytical grade and were used without further purification. Cadmium acetate dihydrate $\left(\mathrm{Cd}\left(\mathrm{CH}_{3} \mathrm{COO}\right)_{2} \cdot 2 \mathrm{H}_{2} \mathrm{O}\right)$, copper(II) chloride dihydrate $\left(\mathrm{CuCl}_{2} \cdot 2 \mathrm{H}_{2} \mathrm{O}\right)$, thioacetamide (TAA) and rare earth metal salts, gadolinium(III) chloride hydrate $\left(\mathrm{GdCl}_{3}\right.$. $\mathrm{H}_{2} \mathrm{O}$ ), terbium(III) chloride $\left(\mathrm{TbCl}_{3} \cdot 6 \mathrm{H}_{2} \mathrm{O}\right)$ hexahydrate and erbium(III) chloride hexahydrate $\left(\mathrm{ErCl}_{3} \cdot 6 \mathrm{H}_{2} \mathrm{O}\right)$ were purchased from Sigma Aldrich. Ethylene glycol (EG) was purchased from Alfa-Aesar. Doubly-distilled water was used for preparing aqueous solutions. PXRD (Powder X-ray Diffraction) patterns were recorded from $10^{\circ}$ to $90^{\circ}$ on Rigaku Miniflex diffractometer using monochromatic $\mathrm{CuK \alpha}$ radiations (The Woodlands, TX, USA). Scanning electron micrographs (SEM) were collected on Jeol T-300 scanning electron microscope with gold coating (Tokyo, Japan). Transmission electron micrographs (TEM) were collected on TECNAI $200 \mathrm{kV}$ TEM (Fei, Electron Optics). The particle size was determined by DLS technique using Zetasizer Nano ZS-90 (Malvern Instruments Ltd., Worcestershire, UK). The photoluminescence excitation and emission spectra were recorded at room temperature using Agilent Cary Eclipse Fluorescence Spectrophotometer equipped with a Xenon lamp as an excitation source.

\section{2. Synthesis}

The undoped CdS, CdS doped with $\mathrm{Cu}^{2+}$ and co-doped with $\mathrm{Cu}^{2+}-\mathrm{Gd}^{3+}, \mathrm{Cu}^{2+}-\mathrm{Er}^{3+}, \mathrm{Cu}^{2+}-\mathrm{Tb}^{3+}$ nanoparticles were synthesized by chemical precipitation method in deionized water in air atmosphere. The precipitation of undoped/doped CdS nanoparticles was performed starting with $0.1 \mathrm{M}$ homogeneous solutions each of $\mathrm{Cd}\left(\mathrm{CH}_{3} \mathrm{COO}\right)_{2}$. $2 \mathrm{H}_{2} \mathrm{O}(0.66 \mathrm{~g})$, thioacetamide TAA, $(0.188 \mathrm{~g}), \mathrm{CuCl}_{2}$. $2 \mathrm{H}_{2} \mathrm{O}(0.43 \mathrm{~g}), \mathrm{GdCl}_{3} \cdot \mathrm{H}_{2} \mathrm{O}(0.658 \mathrm{~g}), \mathrm{ErCl}_{3} \cdot 6 \mathrm{H}_{2} \mathrm{O}(0.954$ $\mathrm{g}), \mathrm{TbCl}_{3} \cdot 6 \mathrm{H}_{2} \mathrm{O}(0.932 \mathrm{~g})$ each in $25 \mathrm{~mL}$ of distilled water. The temperature of each solution was maintained $80{ }^{\circ} \mathrm{C}$ and $\mathrm{pH}$ was kept at 2 to avoid the decomposition of TAA at premature stage.

For the synthesis of undoped CdS nanoparticles, aqueous solution of TAA was added to the solution of $\mathrm{Cd}\left(\mathrm{CH}_{3} \mathrm{COO}\right)_{2} \cdot 2 \mathrm{H}_{2} \mathrm{O}$ dropwise while stirring on magnetic stirrer. The reaction temperature was maintained at $80{ }^{\circ} \mathrm{C}$ throughout. Stirring was done for 5 hours at constant temperature and the reaction was terminated by rapidly cooling the reaction mixture in an ice bath. The as-precipitated undoped sample was centrifuged at $3000 \mathrm{rpm}$ for $30 \mathrm{~min}$., washed with water and isopropyl alcohol several times and then dried at $70{ }^{\circ} \mathrm{C}$ for 2 hours.

To synthesize $\mathrm{Cu}^{2+}$ doped $\mathrm{CdS}$ nanoparticles, $0.1 \mathrm{M}$ aqueous solutions of $\mathrm{Cd}\left(\mathrm{CH}_{3} \mathrm{COO}\right)_{2} \cdot 2 \mathrm{H}_{2} \mathrm{O}(0.66 \mathrm{~g})$ and $\mathrm{CuCl}_{2} \cdot 6 \mathrm{H}_{2} \mathrm{O}(0.43 \mathrm{~g})$ were mixed and stirred for $30 \mathrm{mi}-$ nutes. To this, $0.1 \mathrm{M}$ solution of TAA was added dropwise while stirring with reaction temperature maintained at 80 ${ }^{\circ} \mathrm{C}$. All reaction conditions and procedure adopted were same as above.

In a typical synthesis for $\mathrm{Cu}^{2+}$ and rare earth metallic ions co-doped $\mathrm{CdS}$ nanoparticles, $0.1 \mathrm{M}$ aqueous solutions of $\mathrm{Cd}\left(\mathrm{CH}_{3} \mathrm{COO}\right)_{2} \cdot 2 \mathrm{H}_{2} \mathrm{O}, \mathrm{CuCl}_{2} \cdot 2 \mathrm{H}_{2} \mathrm{O}$ and rare earth metallic ions were mixed and stirred for 30 minutes. To this mixture, $0.1 \mathrm{M}$ solution of TAA was added dropwise while stirring with reaction temperature maintained at $80{ }^{\circ} \mathrm{C}$. The rest of procedure and reaction conditions were kept similar as for above synthesized nanoparticles.

\section{Results and Discussion}

\section{1. PXRD Measurements}

The structural characterization of the nanoparticles has been carried out by X-ray diffraction technique using $\mathrm{CuK \alpha}$ radiation. PXRD patterns of synthesized undoped and doped CdS nanoparticles are shown in Figure 1. The synthesized particles produce highly intense X-ray reflections in their corresponding PXRD pattern indicating that all the compounds are crystalline in nature. All PXRD pat- 


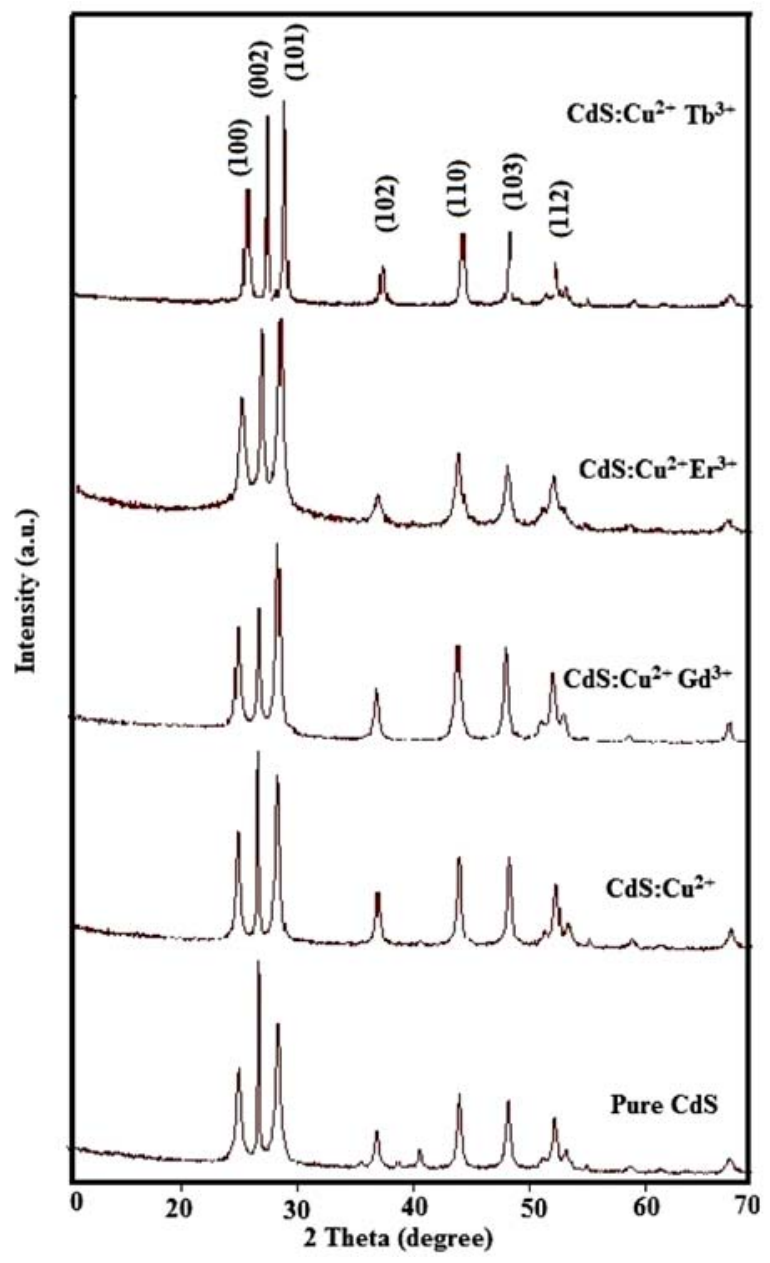

Figure 1. PXRD patterns for (a) undoped $\mathrm{CdS}$ (b) $\mathrm{CdS}: \mathrm{Cu}^{2+}$ (c) $\mathrm{CdS}: \mathrm{Cu}^{2+} \mathrm{Gd}^{3+}(\mathrm{d}) \mathrm{CdS}: \mathrm{Cu}^{2+} \mathrm{Er}^{3+}$ (e) $\mathrm{CdS}: \mathrm{Cu}^{2+} \mathrm{Tb}^{3+}$

terns show (100), (002), (101), (102), (110), (103) and (112) planes of hexagonal phase of $\mathrm{CdS}$ corresponding to JCPDS File No. 41-1049. All the peaks in the diffraction pattern are characteristic of CdS suggesting that incorporation of dopant ion in the sample does not introduce appreciable changes in the crystal structure of CdS. This shows that the hexagonal structure is not modified by the addition of different rare earth metals into the matrix. However, a small deviation in full width at half maxima of diffraction peaks was observed by the addition of doping ions, which may be due to a small variation in the size of metal ions.

Various parameters such as interplanar spacing ( $\mathrm{d}$ in $\AA)$, crystallite size (D in $\mathrm{nm})$, microstrain $(\varepsilon)$, dislocation density $\left(\rho\right.$ in $10^{15} \mathrm{~m} / \mathrm{m}^{3}$ ) and distortion parameter $(\mathrm{g})$ along the most intense peak were calculated using following well known equations and are shown in Table 1 . The various equations used are,

$$
\begin{aligned}
\mathrm{D}= & 0.9 \lambda / \beta \cos \theta ; \mathrm{d}=\lambda / 2 \sin \theta ; \varepsilon=\beta \cos \theta / 4 ; \rho=1 / \mathrm{D}^{2} \\
& \text { and } \mathrm{g}=\beta / \tan \theta
\end{aligned}
$$

where $\lambda=0.15418 \mathrm{~nm}$ for $\mathrm{Cu}-K \alpha, \beta$ is FWHM (Full Width at Half Maximum) of diffraction peaks and $\theta$ is diffraction angle.

The variation in particle size occurs due to the interaction between the dopants and grain boundaries and this result in change in grain boundary energy. This leads to the stabilization of the surfaces/grain boundaries and variation in particle size. Also, it is clear from above equations that microstrain values decrease with increase in the crystallite size. ${ }^{33}$

In order to distinguish the effects of crystallite size and strain on induced broadening, Williamson-Hall plots of XRD profile have been drawn. ${ }^{34}$ The crystallite size and strain can be obtained from the intercept at y-axis and the slope of line respectively.

$$
\beta_{\mathrm{hkl}} \cos \theta=\mathrm{k} \lambda / \mathrm{D}+4 \varepsilon \sin \theta
$$

where $\beta$ is FWHM in radian, D is the crystallite size in $\mathrm{nm}$, $\varepsilon$ is the strain, $\lambda$ is $\mathrm{X}$-ray wavelength in nanometers. The calculated crystallite sizes are in the range of $46-75 \mathrm{~nm}$.

\section{2. SEM and TEM Analysis}

The morphology of isolated pure and doped CdS nanoparticles was investigated by scanning and transmission electron microscopy (SEM and TEM). Figure 2(a-e) shows SEM images of the un-doped and doped nanoparticles. As is evident from the SEM images, synthesized particles are near spherical in shape and involve aggregation of particles.

Figure 3(a-e) shows TEM images of as synthesized

\begin{tabular}{|c|c|c|c|c|c|c|c|}
\hline Samples & $\begin{array}{c}\text { Peak position } \\
2 \theta \text { (in degrees) }\end{array}$ & $\begin{array}{c}\text { Particle size } \\
\text { D (in nm) }\end{array}$ & $\begin{array}{c}\text { FWHM } \beta \\
\text { (in degrees) }\end{array}$ & $\begin{array}{c}\text { d-value }(\AA) \\
\text { Observed }\end{array}$ & $\begin{array}{r}\text { Dislocat } \\
\text { Calculated }\end{array}$ & $\begin{array}{l}\text { on density } \rho \\
\left(\text { in } 10^{15} \mathrm{~m} / \mathrm{m}^{3} \text { ) }\right.\end{array}$ & $\begin{array}{c}\text { Distortion } \\
\text { parameter } \mathrm{g}\end{array}$ \\
\hline Undoped CdS & 26.804 & 53.62 & 0.1506 & 3.326 & 3.322 & 0.348 & 0.632 \\
\hline $\mathrm{CdS}: \mathrm{Cu}^{2+}$ & 26.816 & 32.18 & 0.2509 & 3.324 & 3.321 & 0.965 & 1.053 \\
\hline $\mathrm{CdS}: \mathrm{Cu}^{2+} \mathrm{Gd}^{3+}$ & 26.731 & 48.26 & 0.1673 & 3.335 & 3.331 & 0.429 & 0.704 \\
\hline $\mathrm{CdS}: \mathrm{Cu}^{2+} \mathrm{Er}^{3+}$ & 28.324 & 37.25 & 0.2175 & 3.151 & 3.147 & 0.721 & 0.862 \\
\hline $\mathrm{CdS}: \mathrm{Cu}^{2+} \mathrm{Tb}^{3+}$ & 28.446 & 26.92 & 0.3011 & 3.137 & 3.133 & 1.379 & 1.188 \\
\hline
\end{tabular}
un-doped and doped nanoparticles. The synthesized nano-

Table 1. Evaluated parameters from XRPD data for undoped and doped CdS nanoparticles 

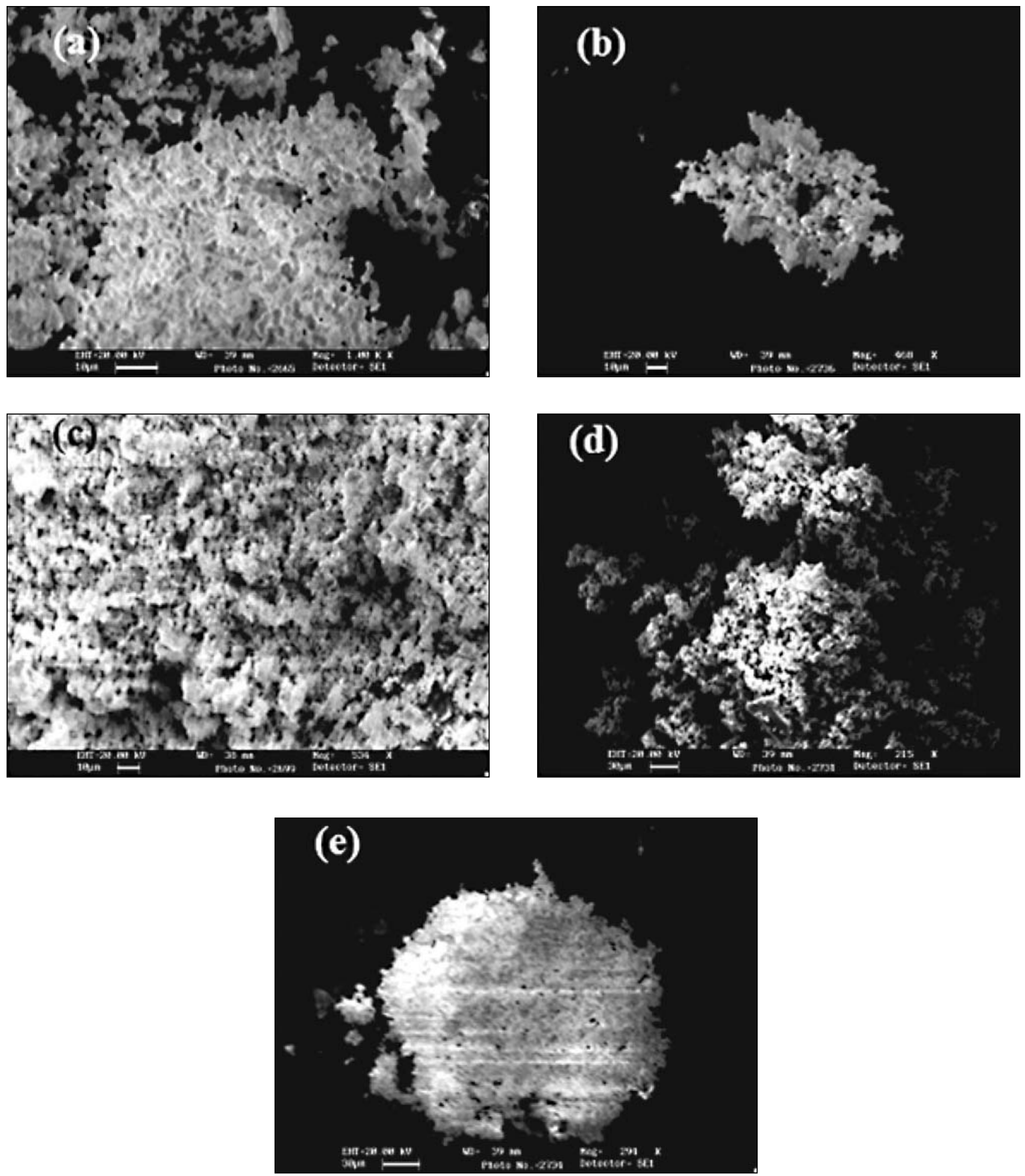

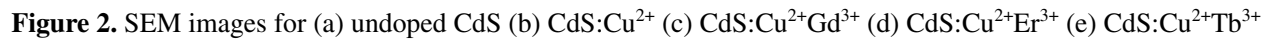

particles have nanoflake like shape. These nanoflakes then assemble to produce nearly spherical aggregates as observed in Figure 3. The particle size obtained from TEM and PXRD are in close agreement. The elemental mapping images shown in Figure 4, confirms the presence of dopants.

\section{3. Particle Size by Dynamic Light Scattering}

The particle size distribution of synthesized CdS nanoparticles was studied by dynamic light scattering technique. Figure 5 displays average particle size distribution 

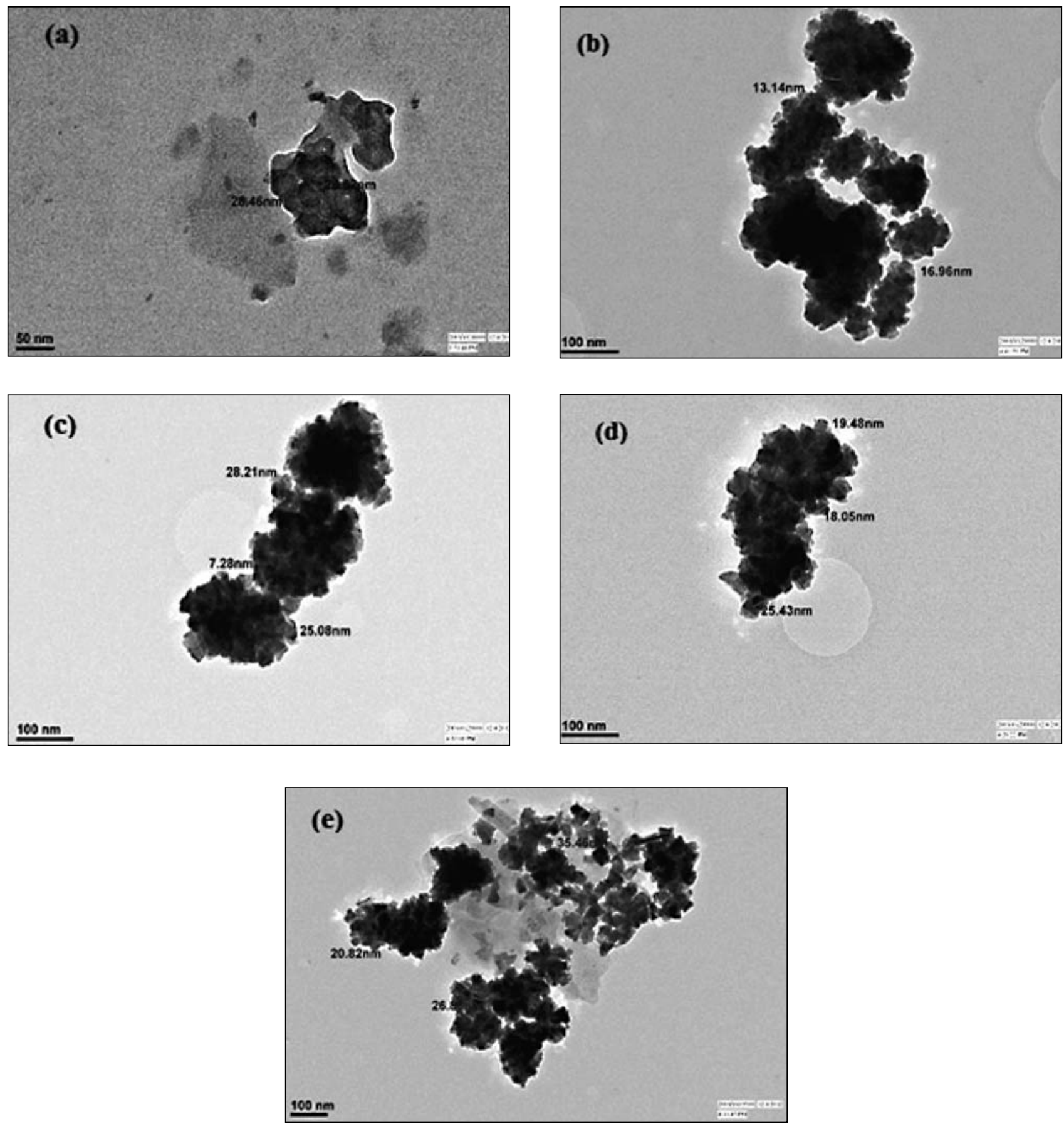

Figure 3. TEM images for (a) undoped $\mathrm{CdS}$ (b) $\mathrm{CdS}: \mathrm{Cu}^{2+}$ (c) $\mathrm{CdS}: \mathrm{Cu}^{2+} \mathrm{Gd}^{3+}$ (d) $\mathrm{CdS}: \mathrm{Cu}^{2+} \mathrm{Er}^{3+}$ (e) $\mathrm{CdS} \mathrm{Cu}^{2+} \mathrm{Tb}^{3+}$

of all the synthesized samples. Nanoparticles were dispersed uniformly in deionized water by mild sonication for 10 minutes before DLS analysis. As observed from Figure 5 , approximate sizes of un-doped and doped CdS nanoparticles are different. Due to surface solvation and agglomeration of particles in colloidal solution, the particle size analyzed from DLS method is usually larger in comparison to the particle sizes calculated from XRPD data. The particle sizes obtained from DLS are shown in Table 2.
Table 2. Particle size obtained from DLS technique and TEM

\begin{tabular}{ccc}
\hline Samples & $\begin{array}{c}\text { Particle size by } \\
\text { DLS (in nm) }\end{array}$ & $\begin{array}{c}\text { Particle size from } \\
\text { TEM(in nm) }\end{array}$ \\
\hline Undoped CdS & 80.6 & 28.5 \\
$\mathrm{CdS}: \mathrm{Cu}^{2+}$ & 109 & 15 \\
$\mathrm{CdS}: \mathrm{Cu}^{2+} \mathrm{Gd}^{3+}$ & 134 & 20 \\
$\mathrm{CdS}: \mathrm{Cu}^{2+} \mathrm{Er}^{3+}$ & 172 & 21 \\
$\mathrm{CdS}: \mathrm{Cu}^{2+} \mathrm{Tb}^{3+}$ & 164 & 42 \\
\hline
\end{tabular}



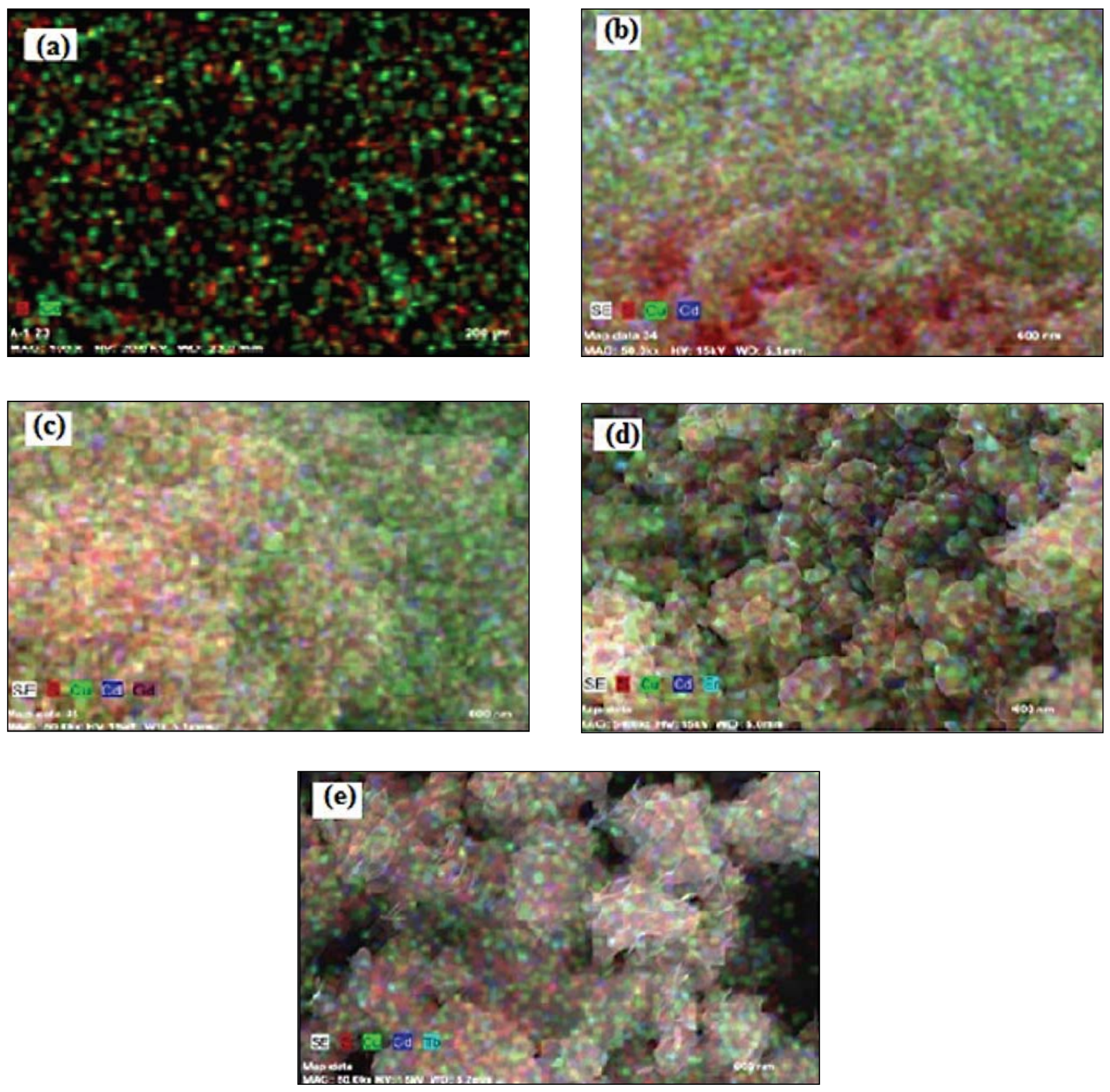

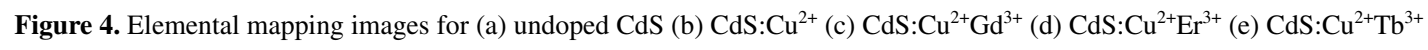

Size Distribution by Intensity

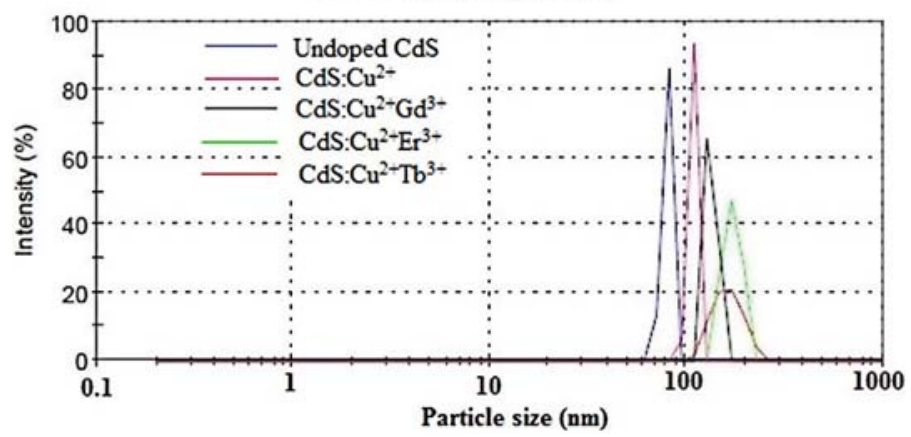

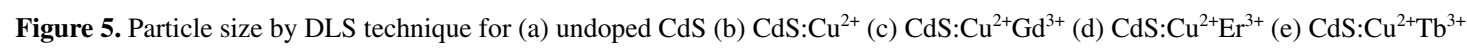




\section{4. Absorption Spectra}

UV-Visible absorption spectroscopy is an efficient technique to monitor the optical properties of nanomaterials which are directly related to particle size. The absorption spectra of un-doped $\mathrm{CdS}, \mathrm{CdS}: \mathrm{Cu}^{2+}$ doped and $\mathrm{CdS}: \mathrm{Cu}^{2+}, \mathrm{Ln}^{3+}$ co-doped nanoparticles are shown in Figure 6. For recording absorption spectra of samples, asprepared nanoparticles were dispersed in isopropyl alcohol by ultrasonication for about 30 minutes to obtain nearly monodisperse solution. The absorption peaks of undoped and doped CdS are considerably blue shifted compared to that of the bulk phase CdS ( $\lambda_{\max } 515 \mathrm{~nm}$ and band gap $=2.41 \mathrm{eV}) .{ }^{35}$ This blue shift in absorption is due to decrease in particle size in comparison to the bulk material. ${ }^{36}$ This shift in band gap occurs because with decreasing size, binding energy of exciton increases due to the increasing columbic overlap enforced by spatial localization of the wave functions. A significant increase in absorption intensity has been observed for $\mathrm{Cu}^{2+}, \mathrm{Ln}^{3+}$ co-doped CdS nanoparticles. The absorption shoulder edge is found to vary with change in the dopant ion as doped ions can affect the band gap structure of the host materials.

The optical bandgap of the undoped and doped CdS was calculated using equation:

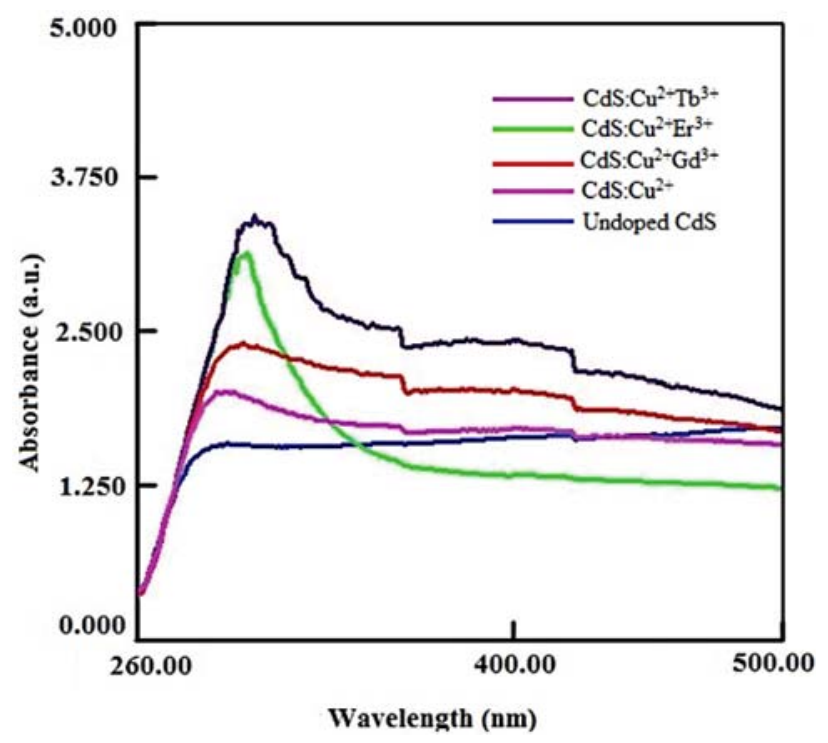

Figure 6. Absorption spectra for (a) undoped $\mathrm{CdS}$ (b) $\mathrm{CdS}: \mathrm{Cu}^{2+}$ (c) $\mathrm{CdS}: \mathrm{Cu}^{2+} \mathrm{Gd}^{3+}$ (d) $\mathrm{CdS}: \mathrm{Cu}^{2+} \mathrm{Er}^{3+}$ (e) $\mathrm{CdS}: \mathrm{Cu}^{2+} \mathrm{Tb}^{3+}$

Table 3. Absorption wavelength and calculated bandgap

\begin{tabular}{ccc}
\hline Samples & $\boldsymbol{\lambda} / \mathbf{n m}$ & $\boldsymbol{E}_{\boldsymbol{g}} / \mathbf{e V}$ \\
\hline Undoped CdS & 275 & 4.50 \\
$\mathrm{CdS}: \mathrm{Cu}^{2+}$ & 285 & 4.35 \\
$\mathrm{CdS}: \mathrm{Cu}^{2+} \mathrm{Gd}^{3+}$ & 290 & 4.27 \\
$\mathrm{CdS}: \mathrm{Cu}^{2+} \mathrm{Er}^{3+}$ & 304 & 4.07 \\
$\mathrm{CdS}: \mathrm{Cu}^{2+} \mathrm{Tb}^{3+}$ & 308 & 4.02 \\
\hline
\end{tabular}

$$
E_{g}=\mathrm{hc} / \lambda=1240 / \lambda
$$

where $E_{g}$ is the bandgap in $\mathrm{eV}, \lambda$ is the wavelength in $\mathrm{nm}$. The calculated band gap for the samples is given in Table 3 .

\section{5. Photoluminescence Studies}

The photoluminescence spectra of un-doped CdS, $\mathrm{CdS}: \mathrm{Cu}^{2+}$ doped and $\mathrm{CdS}: \mathrm{Cu}^{2+}, \mathrm{Ln}^{3+}$ co-doped nanoparticles are displayed in Figure 7. The effect of doping on emission spectra of synthesized $\mathrm{CdS}$ nanoparticles has been investigated. Nanoscale particles show higher luminescent intensities than bulk material as they have higher surface/volume ratio and more surface states and thus, contain more accessible carriers for photoluminescence. ${ }^{37}$ The peak position in all the samples is same. However, intensity is significantly changed. Strong photoluminescent emission is due to increased recombination of electrons trapped inside sulfur vacancy with holes in the valence band. A strong emission band centred at about $545 \mathrm{~nm}$ is observed for all the synthesized (un-doped and doped) samples at an excitation of about $254 \mathrm{~nm}$. For CdS: $\mathrm{Cu}^{2+}$, $\mathrm{Ln}^{3+}$ co-doped nanoparticles, intensity is remarkably enhanced in comparison to un-doped CdS nanoparticles. In this case, composite luminescence centres of $\mathrm{Cu}^{2+}$ and rare-earth metallic ions are formed. The electrons are excited from the valence band to the conduction band on absorbing ultraviolet photons and are trapped by the defects. Recombination of defects and excited states induced by the composite centre of $\mathrm{Cu}^{2+}$ and $\mathrm{Ln}^{3+}$ ions occurs and emission of visible light is observed. When $\mathrm{Cu}^{2+}$ and $\mathrm{Ln}^{3+}$ are doped as activation ions in $\mathrm{CdS}$ nanoparticles, more electrons are easily excited and radiative recombination of luminescence process is enhanced. Thus, relative luminescence intensity of co-doped samples is dramatically enhanced. ${ }^{38}$ M. Rajesh Kumar et al. reported a strong emis-

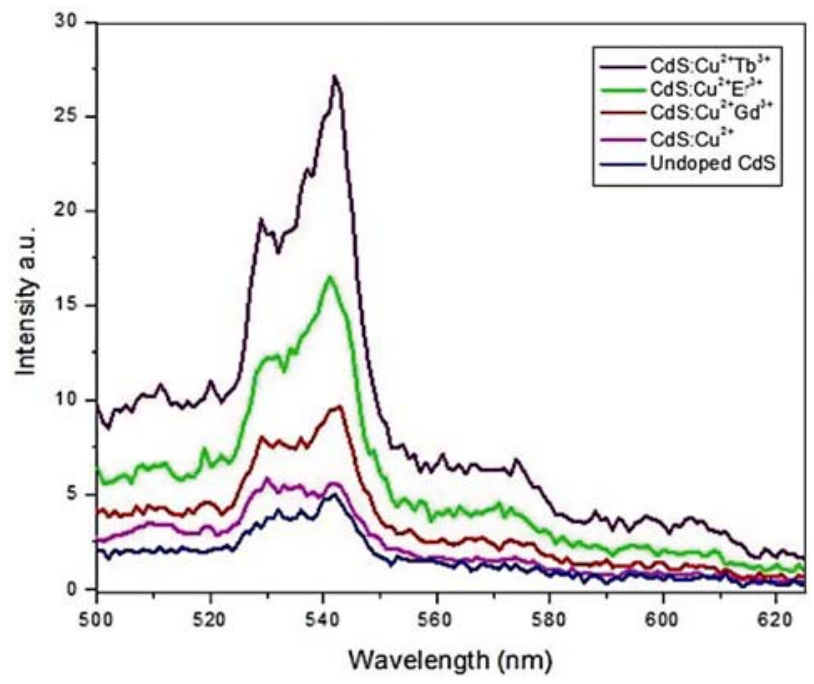

Figure 7. Photoluminescence spectra for (a) undoped CdS (b) Cd$\mathrm{S}: \mathrm{Cu}^{2+}$ (c) $\mathrm{CdS}: \mathrm{Cu}^{2+} \mathrm{Gd}^{3+}$ (d) $\mathrm{CdS}: \mathrm{Cu}^{2+} \mathrm{Er}^{3+}$ (e) $\mathrm{CdS}: \mathrm{Cu}^{2+} \mathrm{Tb}^{3+}$ 
sion peak at $535 \mathrm{~nm}$ with a weak green emission peak at $575 \mathrm{~nm}$ for Mn doped CdS nanoparticles capped with PVP. ${ }^{39}$ Due to strong emission in visible region, these nanoparticles can find applications in optical devices and light emitting diodes.

\section{Conclusions}

$\mathrm{CdS}$ nanoparticles doped with $\mathrm{Cu}^{2+}$ and co-doped with $\mathrm{Cu}^{2+}-\mathrm{Gd}^{3+}, \mathrm{Cu}^{2+}-\mathrm{Er}^{3+}, \mathrm{Cu}^{2+}-\mathrm{Tb}^{3+}$ were obtained by co-precipitation method. The PXRD results suggest that co-doping does not alter the PXRD pattern of CdS nanoparticles. A blue shift in absorption maximum is observed which might be due to the formation of particles in the nanometer scale. PL experiments show very strong emission in visible region from co-doped nanoparticles at room temperature. The emission peak of un-doped CdS is centered at about $545 \mathrm{~nm}$. Although the peak position of doped and co-doped $\mathrm{CdS}$ nanopaticles is at the same position but their fluorescence intensities are remarkably enhanced compared to un-doped CdS nanoparticles.

\section{Acknowledgements}

We gratefully acknowledge Sophisticated Analytical Instrumentation Facility, Panjab University, Chandigarh, for powder X-ray diffraction study. We thank, All India Institute of Medical Sciences (AIIMS), New Delhi for transmission electron microscopy. The authors thank Dr. Vinay Kumar, Assistant Professor, School of Physics, Shri Mata Vaishno Devi University (SMVDU) for photoluminescence studies.

\section{References}

1. E. L. Wolf, in Nanophysics and Nanotechnology: An Introduction to Modern Concepts in Nanoscience, Wiley-VCH, Weinheim, 2nd edn., 2006. http://dx.doi.org/10.1002/9783527618972

2. M. Bruchez, M. Moronne, P. Gin, S. Weiss, A. P. Alivisatos, Science 1998, 281, 2013-2016. http://dx.doi.org/10.1126/science.281.5385.2013

3. J. Planelles, J. G. Diaz, J. Climente, W. Jaskolski, Phys. Rev. B 2002, 65, 245302 (1-7).

4. U. Woggon, J. Appl. Phys. 2007, 101, 081727 (1-5).

5. M. A. El-Sayed, Acc. Chem. Res. 2004, 37, 326-333. http://dx.doi.org/10.1021/ar020204f

6. W. E. Buhro, V. L. Colvin, Nat. Mater. 2003, 2, 138-139. http://dx.doi.org/10.1038/nmat844

7. S. Iijima, Nature 1991, 354, 56-58. http://dx.doi.org/10.1038/354056a0

8. C. Cheng, G. Xu, H. Zhang, H. Wang, J. Cao, H. Ji, Mat. Chem. Phys. 2006, 97, 448-451.

http://dx.doi.org/10.1016/j.matchemphys.2005.08.045
9. R. A. M. Hikmet, D. V. Talapin, H. Weller, J. Appl. Phys. 2003, 93, 3509-3514.

http://dx.doi.org/10.1063/1.1542940

10. H. T. Xue, P. Q. Zhao, J. Phys. D: Appl. Phys. 2009, 42, 015402 (5pp).

11. R. N. Bhargava, D. Gallagher, X. Hong, A. Nurmikko, Phys. Rev. Lett. 1994, 72, 416-419.

http://dx.doi.org/10.1103/PhysRevLett.72.416

12. P. Yang, M. Lu, D. Xu, D. Yuan, C. Song, G. Zhou, J. Phys. Chem. Solids 2001, 62, 1181-1184. http://dx.doi.org/10.1016/S0022-3697(00)00287-0

13. W. Sang, Y. Qian, J. Min, D. Li, L. Wang, W. Shi, Y. Liu, Solid State Commun. 2002, 121, 475-478. http://dx.doi.org/10.1016/S0038-1098(01)00518-X

14. M. A. Malik, P. O'Brien, N. Revaprasadu, J. Mater. Chem. 2001, 11, 2382-2386. http://dx.doi.org/10.1039/b102709n

15. M. Wang, L. Sun, X. Fu, C. Liao, C. Yan, Solid State Commun. 2000, 115, 493-496. http://dx.doi.org/10.1016/S0038-1098(00)00218-0

16. S. M. Liu, F. Q. Liu, H. Q. Guo, Z. H. Zhang, Z. G. Wang, Solid State Commun. 2000, 115, 615-618. http://dx.doi.org/10.1016/S0038-1098(00)00254-4

17. Y. Kanemitsu, H. Matsubara, C. W. White, Appl. Phys. Lett. 2002, 81, 535-537. http://dx.doi.org/10.1063/1.1494468

18. W. Que, Y. Zhou, Y. L. Lam, Y. C. Chan, C. H. Kam, B. Liu, L. M. Gam, C. H. Chew, G. Q. Xu, S. J. Chua, F. V. C. Mendis, Appl. Phys. Lett. 1998, 73, 2727-2729. http://dx.doi.org/10.1063/1.122571

19. K. Manickathai, S. K. Viswanathan, M. Alagar, Ind. J. Pure Appl. Phys. 2008, 46, 561-564.

20. Y. Wang, Acc. Chem. Res. 1991, 24, 133-139. http://dx.doi.org/10.1021/ar00005a002

21. M. Y. Han, L. M. Gan, W. Huang, C. H. Chew, B. S. Zou, Chem. Lett. 1997, 8, 751-752. http://dx.doi.org/10.1246/cl.1997.751

22. Y. C. Chu, C. C. Wang, C. Y. Chen, Nanotechnology 2005, 16, 58-64. http://dx.doi.org/10.1088/0957-4484/16/1/013

23. T. L. Zhang, Y. S. Xia, X. L. Diao, C. Q. Zhu, J. Nanopart. Res. 2008, 163, 271-276.

24. G. Giribabu, G. Murali, D. Amarnatha Reddy, S. Sambasivam, R. P. Vijaylakshmi, Mater. Lett. 2014, 126, 119-122. http://dx.doi.org/10.1016/j.matlet.2014.04.044

25. A. Sundaria, A. Shrivastav, B. Vijay, R. Soni, S. Goyal, R. Meshugga, K. Agrawal, Macromol. Symp. 2015, 357, 223228. http://dx.doi.org/10.1002/masy.201500036

26. X. Wang, D. Li, Y. Guo, X. Wang, Y. Du, R. Sun, Opt. Mater. 2012, 34, 646-651. http://dx.doi.org/10.1016/j.optmat.2011.09.013

27. M. Thambidurai, N. Muthukumarasamy, D. Velauthapillai, S. Agilan, R. Balasundaraprabu, J. Electron. Mater. 2012, 41, 665-671. http://dx.doi.org/10.1007/s11664-012-1900-5

28. S. Kumar, S. Kumar, S. Jain, N. K. Verma, Appl. Nanosci. 2012, 2, 127-131. http://dx.doi.org/10.1007/s13204-011-0046-8

29. P. Yang, M. Lu, D. Xu, D. Yuan, G. Zhou, J. Lumin. 2001, 93, 101-105. http://dx.doi.org/10.1016/S0022-2313(01)00186-7 
30. H. J. Lozykowski, W. M. Jadwisienkzak, I. Brown, J. Appl. Phys. 2000, 88, 210-222. http://dx.doi.org/10.1063/1.373645

31. J. C. Lee, N. G. Subramaniam, J. W. Lee, T. W. Kang, Appl. Phys. Lett. 2007, 90, 262909(1-3).

32. S. Chandramohan, A. Kanjilal, J. K. Tripathi, S. N. Sarangi, R. Sathyamoorthy, T. Som, J. App. Phys. 2009, 105, 123507 (1-4).

33. A. L. Dawar, P. K. Shishodia, G. Chauhan, A. Kumar, P. C. Mathur, Mater. Sci. Lett. 1990, 9, 547-548. http://dx.doi.org/10.1007/BF00725872

34. G. K. Williamson, W. H. Hall Acta Metall 1953, 1, 22-31. http://dx.doi.org/10.1016/0001-6160(53)90006-6
35. P. S. Nair, N. Revaprasadu, T. Radhakrishnana, G. A. Kolawolea, J. Mater. Chem. 2001, 11, 1555-1556. http://dx.doi.org/10.1039/b100697p

36. J. Nanda, S. Sapra, D. D. Srama, N. Chandrasekharan, G. Hodes, Chem. Mater. 2000, 12, 1018-1024. http://dx.doi.org/10.1021/cm990583f

37. W. Chen, Z. G. Wang, Z. J. Lin, L. Y. Lin, Appl. Phys. Lett. 1997, 70, 1465-1467. http://dx.doi.org/10.1063/1.118563

38. P. Yang, M. Lu, G. Zhou, D. Yuan, D. Xu, Inorg. Chem. Commun. 2001, 4, 734-737. http://dx.doi.org/10.1016/S1387-7003(01)00322-7

39. M. R. Kumar, G. Murugadoss, J. Lumin. 2014, 146, 325332. http://dx.doi.org/10.1016/j.jlumin.2013.09.048

\section{Povzetek}

S koprecipitacijsko metodo smo sintetizirali nanodelce kadmijevega sulfida (CdS), dopirane s kovinskimi ioni bakra $\left(\mathrm{Cu}^{2+}\right)$ in redkozemeljskih kovin $\left(\mathrm{Ln}^{3+}\right)$. Nanodelce smo ustrezno karakterizirali z naslednjimi tehnikami: rentgenska praškovna analiza (PXRD), vrstična elektronska mikroskopija (SEM), presevna elektronska mikroskopija (TEM), dinamično sipanje svetlobe (DLS), UV-VIS spektroskopija in fotoluminiscenca (PL). Nanodelce CdS lahko dopiramo z ioni bakra in redkozemeljskih kovin, pri čemer ni zaznati sprememb na rentgenskem praškovnem posnetku. SEM in TEM rezultati kažejo na sferično agregacijo sintetiziranih delcev. V absorpcijskih spektrih vseh vzorcev je prisoten močan modri premik glede na CdS. S fotoluminiscenco pa smo opazili povečane intenzitete v primeru dopiranih CdS nanodelcev pri sobni temperaturi. 